\title{
OVERVIEW AND COMPARISON OF LEGIONELLA REGULATIONS WORLDWIDE
}

Van Kenhove Elisa ${ }^{\mathrm{a},}{ }^{*}$, Dinne Karla ${ }^{\mathrm{b}}$, Janssens Arnold ${ }^{\mathrm{c}}$, Laverge Jelle ${ }^{\mathrm{d}}$

a,c,d Research group Building Physics, Construction and Climate Control. Department of Architecture and Urban Planning. Ghent University. Sint Pietersnieuwstraat 41 B4, 9000 Ghent, Belgium

${ }^{b}$ WTCB-CSTC-BBRI (Belgian Building Research Institute). Avenue Pierre Holoffe 21, 1342 Ottignies-Louvainla-Neuve, Belgium

*Corresponding author: Elisa.VanKenhove@UGent.be, +32 (0)9 2647861

${ }^{\mathrm{a}} 0000-0002-4648-0551,{ }^{\mathrm{c}} 0000-0003-4950-4704,{ }^{\mathrm{d}} 0000-0002-5334-1314$ 


\section{ABSTRACT}

Background: Legionnaires' Disease occurs worldwide. Many authorities have guidelines and regulations to prevent and control Legionella in water systems. These regulations are based on often very limited field and laboratory observations and measurements. They are, therefore, very different from country to country. This paper aims to map the existing regulatory framework on Legionella control in the world in order to assess the feasibility of regulatory unification.

Methods: The paper gives an overview of the different standards, guidelines and recommendations and of how various authorities and/or countries deal with Legionella infection. A three-step process is followed to identify current regulations.

Results: Although Legionella is a global concern with a common scientific base, the regulatory framework is different from country to country. The current guidelines and standards are not the best possible ones, still there is a broad unification of underlying principles despite different regulatory frameworks. Common principles across regulations are avoiding and monitoring critical spots, avoiding water stagnation and the requirement of sufficiently high temperature (above $60^{\circ} \mathrm{C}$, below $25^{\circ} \mathrm{C}$ ). Differences between regulations are the target group and dangerous Legionella concentration levels.

Discussion and conclusion: The comparative analysis of the frameworks is a good starting point to reach future regulatory unification based on their common ground.

\section{KEYWORDS}

Legionella guideline, Legionella standard, Legionella regulation 


\section{INTRODUCTION}

\section{Background Legionella}

Legionnaires' Disease (Legionellosis) is believed to occur worldwide. 39 species of Legionella have been identified. The most common and dangerous for human is Legionella pneumophila. L. pneumophila exists as part of the natural microbial flora of many aquatic ecosystems. L. pneumophila appears in most water supplies like lakes, ponds and rivers in low concentration and in dormant stage, but L. pneumophila bacteria from natural habitats can be increased markedly in man-made hot water systems where the temperature is optimal for their growth and can reach a dangerous concentration. ${ }^{1}$

Various countries have different recommended strategies to prevent L. pneumophila growth. Important differences can be noted in the way they measure dangerous concentrations when it comes to water sampling frequency, $L$. pneumophila alert levels and required actions. These recommended strategies depend on local regulations, while the problem is occurring worldwide since Legionella is naturally present in water. Geographical differences are not sufficiently significant to require customization of infection control practice by region.

The incidence of community-acquired Legionnaires' Disease varies widely according to the level of surveillance and reporting. In the USA, reported cases of Legionnaires' Disease have grown by nearly four and a half times since 2000. It is unclear whether this increase happened due to increased awareness and testing, increased susceptibility of the population, increased Legionella presence in the environment, or a combination of factors. ${ }^{2}$ In Europe, the USA and Australia there are about 10-15 cases reported annually per million population. ${ }^{3}$ This $^{\text {is }}$ still believed to be a serious underestimation since many countries lack appropriate methods of diagnosing the infection or sufficient surveillance systems. This means the actual rate of occurrence is unknown.

Many countries have guidelines or standards for the control of Legionella in water systems and for the prevention of Legionellosis. These guidelines and standards are based on field and laboratory observations and measurements. In this paper, existing guidelines and standards are identified and investigated to get an insight in how and whether or not the scientific knowledge about Legionella growth is translated into these documents. The paper also provides an overview of the most relevant features of existing Legionella standards and guidelines.

For better understanding, technical terms used throughout the paper are visually indicated on the system in Figure 1. 


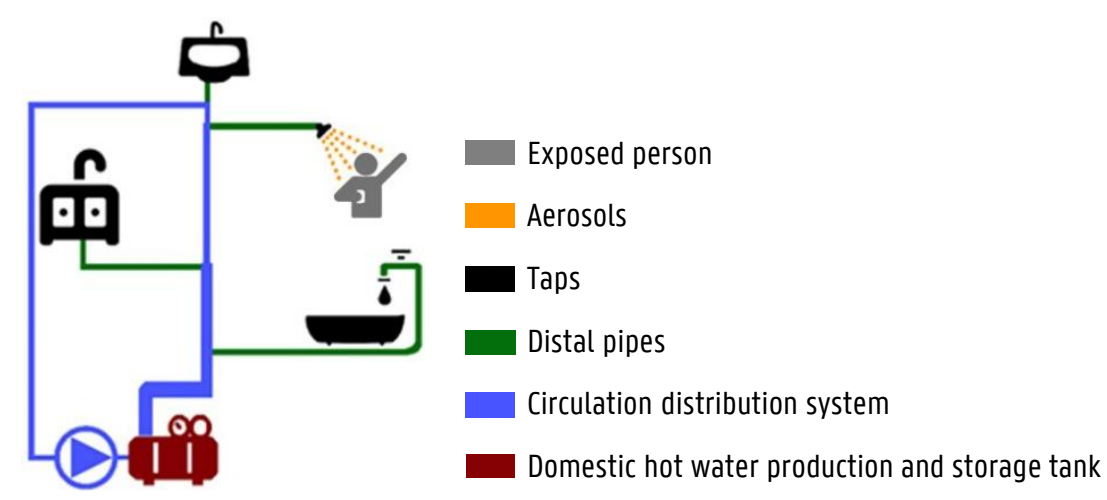

Figure 1. Domestic hot water system with indication of components (adapted from ${ }^{4}$ ).

\section{Why more uniform regulation is needed}

More uniform regulations are needed, although there are different environmental circumstances worldwide. Since 1985, studies have shown that Legionella is present in all segments of community water supplies, including treatment facilities. ${ }^{5,6,7,8}$ The 1985 Legionella Criteria Document states that Legionella is widely distributed in the natural environment worldwide. ${ }^{9}$ Legionella exhibits the ability to survive in an extremely wide range of conditions in natural and man-made aquatic habitats. Its survival is enhanced by symbiotic relationships with other microorganisms. For example, Legionella has the unique ability to multiply within protozoan cells, which helps it survive over a wide temperature range and resist the effects of chlorine, biocides, and other disinfectants.

Current regulations enclose a wide range of climatologic circumstances and no different measures are recommended for different environmental circumstances worldwide. The reason being that the environmental circumstance is not important with regards to Legionella growth, what does matter is the design of the Domestic Hot Water (DHW) system in a building. This is independent of the dominating climate.

Seasonal changes in environmental humidity do not influence the etiology of Legionella infections. ${ }^{10}$ There is only one environmental parameter that is important, which is the fresh water temperature. In case of too high temperature (in warmer countries) some regulations allow chemical disinfection because a significant correlation is observed between higher fresh water temperatures and the presence of L. pneumophila. But the same circumstances ensure whether or not growth will occur because this is not dependent on the dominant climate but on the domestic hot water installation characteristics. A higher fresh water temperature only provokes a time shift in Legionella growth, meaning growth will occur earlier in warmer countries.

Hence comparing these frameworks can be a start to reach future unification of regulations. More uniform, clear and unambiguous regulations would facilitate their implementation in practice. 


\section{METHODS: OVERVIEW OF LEGIONELLA REGULATIONS}

Guidelines are advisory, whereas standards and codes of practice have a more formal standing and are supported by legislative enforcement. From this point in the paper, the word "regulations" is used to refer to all categories. Current regulations vary in scope, but usually include certain common features, such as a risk management approach. This plan can include specific information on managerial responsibility and operator competency. ${ }^{11}$ Some guidelines are very broad, ${ }^{12,13}$ whereas others deal with specific circumstances, such as infection control within health care facilities ${ }^{14,15,16}$ or travel-related disease. ${ }^{17,18,19,20,21,22}$

In the next sections, a description is given of how the regulations, included in this paper, are identified in order to be methodologically reproducible. Afterwards, the most relevant regulations are discussed. First, the authors focus on worldwide standards, secondly regional and national standards are discussed.

\section{Methodology for identifying regulations}

Identification of current guidelines has happened in three subsequently steps. First, the authors performed a literature review where Legionella research was classified based on the geographic context. Based on this identification, experts per region were contacted and questions were asked about the current guidelines and standards in their country. In parallel, government websites were researched to identify missing documents. As a final step documents were translated.

\section{Literature review on Legionella}

A standard literature review starts by searching online subscription-based scientific citation indexing service websites. However, guidelines, standards or regulations cannot be found in this way. In this paper, a literature search is performed only with the aim to identify the most influencing researchers on the topic of Legionella.

In Figure 2 published research about Legionella is shown over the years. When performing a literature search for keyword "Legionella" in scientific journals in all fields, meaning the word Legionella appears at least once in the whole paper, 15589 results were found. Since the 1970's research on Legionella has been published. The number of papers has been increasing from 1979 to 2018. When looking for the more specific keyword "Legionella pneumophila" (all combinations of capitals) in all fields 7615 results were found. The curve is an offset of the curve in Figure 2, meaning publications follow a similar evolution over time. 
The next step was looking in literature for keyword "Legionella pneumophila" in abstract, title and keywords of journal papers, meaning the words Legionella pneumophila appear at least once in the abstract, title or keyword sections instead of in the paper as a whole, 1109 results were found from 1979 to 2016, following the same trend as the curve in Figure 2A, with a peak in 2014.

Because regulations are focusing on Legionella pneumophila in Domestic Hot Water (DHW) the next step was to look for combined keywords "Legionella pneumophila" AND "domestic hot water" or "Legionella pneumophila" AND "DHW" in all fields. This resulted in only 45 hits (Figure 2B).

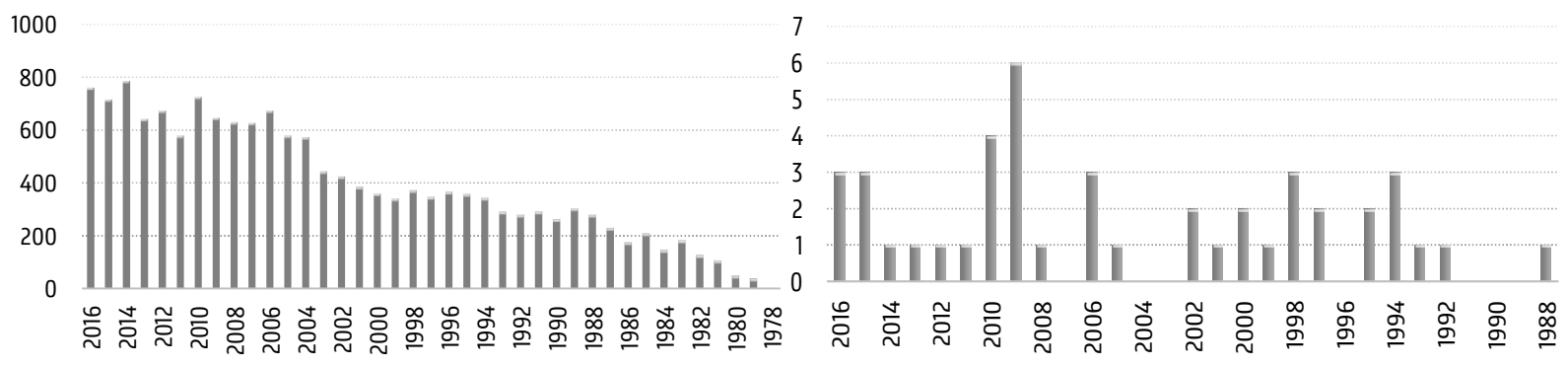

Figure 2. A. Literature search on keyword "Legionella" in all fields gave 15589 results. B. Literature search of "Legionella pneumophila" AND "domestic hot water" in all fields gave 45 results.

These results were looked into in more detail. The results are divided into different categories of geographical context of the paper (country where the research was executed, in most cases equal to the country where a case study was conducted) (Figure 3).

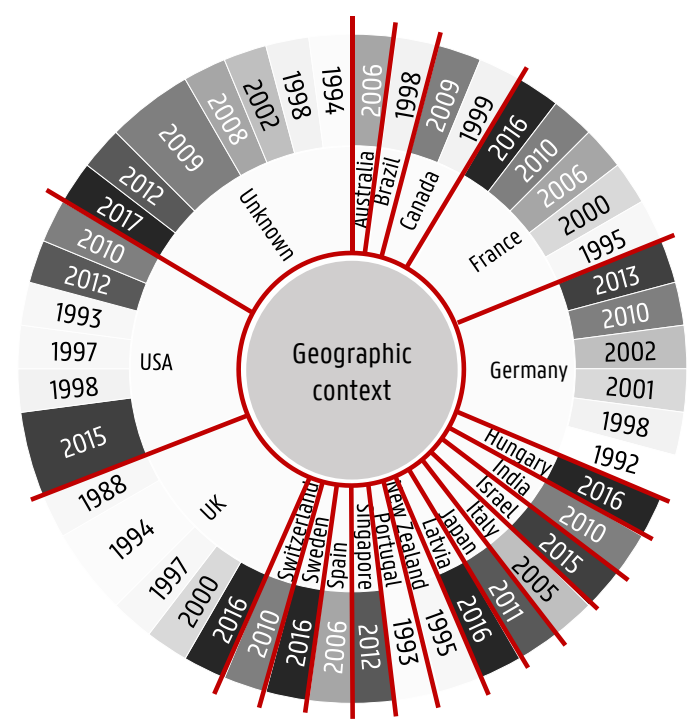

Figure 3. Research on "Legionella pneumophila" AND "domestic hot water" divided in geographic context. 
Based on this last literature search step, experts per country/region were identified and contacted. Questions were asked about the current guidelines and standards in their country/region. In parallel government websites were researched to identify missing documents.

The authors started on macro-scale with clearly identifiable parts of the world, while narrowing the focus in the next steps. More attention is given to industrialized countries because they have central water systems that enhance bacteria growth. This methodology does not guarantee completeness but most of the world and especially the regions with most Legionella infections are covered. As a final step all collected documents were translated.

\section{Legionella regulations worldwide}

\section{World Health Organisation}

The goal of the World Health Organisation (WHO) is to build a healthier future for people all over the world. Working through offices in more than 150 countries, WHO works side by side with governments and other partners to ensure the highest attainable health level. WHO currently provides information and guidance on Legionella risk assessment and management in seven principal documents (Appendix A).

These documents review the current state of knowledge about the impact of Legionella on health. They provide an overview of the sources, ecology and laboratory identification of Legionella. They provide guidance on assessment and management of risks associated with potentially hazardous environments. The documents also identify necessary measures to prevent or adequately control the Legionella exposure risk for each particular environment. WHO gives some information about preferential temperatures for cold water, they state that to prevent Legionella infection, the recommended temperature for cold water storage and distribution is below $25^{\circ} \mathrm{C}$, and ideally below $20^{\circ} \mathrm{C}$. For hot water they only state that maintaining its temperature within buildings is an important control measure to prevent or minimize Legionella growth. No quantitative information about critical levels is mentioned. WHO states that health-based targets usually focus on controlling the proliferation of Legionella and the production and release of aerosols, because of the difficulty of determining what represents an acceptable limit level for Legionella. Sometimes health-based target levels for Legionella safety are however set nationally and applied locally. 


\section{European Union}

\section{European Working Group for Legionella Infections (government)}

The European Working Group for Legionella Infections (EWGLI) was formed in 1986. Its membership comprises scientists with an interest in improving knowledge and information on the epidemiological and microbiological (clinical and environmental) aspects of Legionnaires' Disease. EWGLI is coordinated and managed by the European Centre for Disease Prevention and Control (ECDC) in Sweden. ${ }^{23}$

The technical guidelines formulated by the EWGLI are supportive to all Member States of the European Commission. ${ }^{24}$ This makes the information more concise and less specific. Furthermore, the measures are valid for both cold and hot water installations. On the other hand, the scope of application is not restricted to public establishments, while it is in some Member States regulations.

The possible measures put forward by EWGLI can be divided into three methods of which each independently can limit the growth of L. pneumophila. First, proper monitoring of the DHW system is of great importance. Critical spots need to be inspected properly in order to notice problems quickly to limit possible infection. The principles are mentioned in Appendix A. Secondly, the most commonly used measure in many countries is the requirement of a sufficiently high temperature at the storage tank to prevent L. pneumophila growth. An overview of measures affecting the temperature in the installation is given in Appendix A. Thirdly, water stagnation in certain parts of the systems should be avoided to prevent proliferation of L. pneumophila. Possible measures are given in Appendix A.

The critical L. pneumophila concentrations and associated measures according to EWGLI are summarized in Table 1 .

\begin{tabular}{|c|c|c|}
\hline \multicolumn{2}{|c|}{ Concentration limit } & Measure \\
\hline \multirow[t]{2}{*}{$\begin{array}{l}\text { Between } \\
1000 \text { and } \\
10000 \mathrm{cfu} / 1\end{array}$} & $<20 \%$ of samples & $\begin{array}{l}\text { Resampling necessary } \\
\text { If after resampling a similar amount of samples are infected, it is } \\
\text { recommended to take measures to lower the concentration }\end{array}$ \\
\hline & $>20 \%$ of samples & $\begin{array}{l}\text { Obligation to take measures to decrease concentration } \\
\text { Disinfection should be considered }\end{array}$ \\
\hline $\begin{array}{l}\text { More than } \\
10000 \mathrm{cfu} / 1\end{array}$ & & $\begin{array}{l}\text { Resampling necessary } \\
\text { Take immediate action to lower the concentration, for example: } \\
\text { disinfection }\end{array}$ \\
\hline
\end{tabular}

Table 1. Critical concentrations of L. pneumophila according to EWGLI. ${ }^{\text {Eror! Bookmark not defined. }}$ 
The critical concentrations as set by EWGLI can be interpreted by each country separately. An example is given of limit values for Legionella concentrations in health care settings in France where two levels are specified. Health care buildings destined for patients with individual risk factors such as the elderly and those with alcoholism or tobacco addiction need to comply with:

- $\quad$ Target level $\quad<1000 \mathrm{cfu} / \mathrm{L}$ L. pneumophila

- Alert level $1000 \mathrm{cfu} / \mathrm{l}$ L. pneumophila

- Maximum level $10000 \mathrm{cfu} / \mathrm{l}$ L. pneumophila

For high-risk patients, such as those with severe immunodepression, transplantation, ... the target levels are stricter:

- Target level not detectable

- Alert level 250cfu/l Legionella spp.

Because a count of $0 \mathrm{cfu} / \mathrm{l}$ of L. pneumophila does not guarantee a total absence of the bacterium, it is very difficult to eradicate L. pneumophila from a complex DHW system. Counting of viable and culturable L. pneumophila bacteria is done by accredited laboratories working with ISO or local standards that should also be linked to International Standard ISO 11731-2. ${ }^{25}$

\section{REHVA (industry)}

REHVA Guidebook no. 18 about Legionellosis Prevention in Building water and HVAC Systems was published

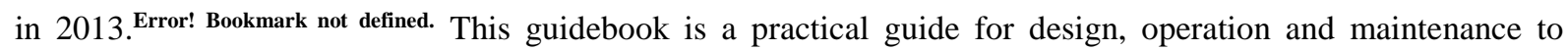
minimize the risk of Legionellosis in building water and HVAC systems. The subject of the guidebook is installations that are at the highest risk level: air conditioning (with humidification), production of hot water for washing, evaporative cooling towers and energy efficient (i.e. low temperature) installations.

\section{Authorities of European countries}

First two examples of EGWLI implementation are discussed, followed by an overview of European countries.

\section{Germany}

In Germany, there is Code of practice W551 (2004) for drinking water installations, which recommends some best plumbing practices, as can be seen in Appendix $A .{ }^{26,27}$

In VDI/DVGW Guideline 6023, which focuses on water installations, action limits are determined and the importance of staff qualification and training is emphasized. As for action levels, Germany is following the levels determined by the European Union. ${ }^{28}$ They add that when $10000 \mathrm{cfu} / 100 \mathrm{ml}$ is measured, immediate action should 
be taken. This concentration is ten times higher than the highest action level set by EWGLI. W556 (2015) contains a flowchart about actions required when an existing drinking water installation is infected.

\section{Belgium}

In Belgium, Legionellosis is a notifiable disease. The critical Legionella levels vary between 1000 and 100 000cfu/l depending on the risk. Belgium's three regions are subject to different regional regulations. Only one guideline and one regulation apply to all of Belgium: hospitals are subject to the Advice of the Health Council and employees are protected from the risks related to biological agents at work by the Codex: KB Biologic Agents (Royal Decree 1996). Additionally in Flanders the Legionella Decree and BBT are applicable. ${ }^{29}$ The BBT gives an overview of the best available techniques for controlling Legionella. In Brussels and Wallonia there are only complementary Legionella regulations regarding public swimming pools and in addition both regions include requirements on cooling towers in their environmental building permit.

\section{Summary of European regulations per country}

Regulations in several European countries are summarized in Table 2. In the first column the country is mentioned, in the second the object for which the regulations apply (in green). In the third column the allowed critical concentration levels are displayed if deviant from the critical concentrations set by EWGLI. In the fourth column the context of the origin of the regulations is listed and in the last column the name of the document is stated with some additional information if relevant. ${ }^{30}$ 


\begin{tabular}{|c|c|c|c|c|c|c|c|c|c|}
\hline \multirow[t]{2}{*}{ Country } & \multicolumn{6}{|c|}{ Object of regulations/guidelines } & \multirow{2}{*}{\begin{tabular}{|l|} 
Critical \\
levels \\
if deviant \\
from EWGLI
\end{tabular}} & \multirow{2}{*}{$\begin{array}{l}\text { Context of } \\
\text { regulation }\end{array}$} & \multirow[t]{2}{*}{ Document } \\
\hline & \begin{tabular}{|l|}
$\begin{array}{l}\text { Drinking } \\
\text { water }\end{array}$ \\
systems \\
\end{tabular} & $\begin{array}{l}\text { Spa } \\
\text { pools }\end{array}$ & $\begin{array}{l}\text { Swim- } \\
\text { ming } \\
\text { pools }\end{array}$ & $\begin{array}{l}\text { Cooling } \\
\text { towers }\end{array}$ & $\begin{array}{l}\text { Aircon- } \\
\text { ditioning } \\
\text { systems }\end{array}$ & $\begin{array}{l}\text { Process } \\
\text { water }\end{array}$ & & & \\
\hline \multirow[t]{2}{*}{ Austria } & & & & & & & & - Health & - Aspects of drinking water (decree of Ministry of Health) \\
\hline & & & & & & & & & $\begin{array}{l}\text { - Systems of swimming pools } \\
\text { - Some provinces: regulations by public health authorities }\end{array}$ \\
\hline \multirow{2}{*}{$\begin{array}{l}\text { Belgium } \\
\text { (Flanders) }\end{array}$} & & & & & & & \multirow{2}{*}{$\begin{array}{l}1000- \\
100000 \\
\mathrm{cfu} / 1\end{array}$} & \multirow{2}{*}{$\begin{array}{l}\text { - Environment } \\
\text { - Public health } \\
\text { - Labor safety } \\
\text { - Biosafety }\end{array}$} & \multirow{2}{*}{$\begin{array}{l}\text { - Guidelines for hospitals and policy rule on working } \\
\text { conditions (KB biological agents) } \\
\text { - Legionella Decree and Code of practice for prevention of } \\
\text { Legionnaires' Disease (BBT) (Fland.) } \\
\text { - Regulation for pools and cooling towers (Bruss. and Wall.) } \\
\text { - Different risk levels covered }\end{array}$} \\
\hline & & & & & & & & & \\
\hline Bulgaria & & & & & & & & - Public health & \\
\hline Croatia & & & & & & & & - Public health & - Guidelines - Law on communicable diseases \\
\hline \multirow{2}{*}{$\begin{array}{l}\text { England } \\
\text { and Wales }\end{array}$} & & & & & & & & - Health and & - Primary legislation, Approved Code of Practice and \\
\hline & & & & & & & & $\begin{array}{l}\text { (management of) } \\
\text { safety at work } \\
\text { - Health } \\
\end{array}$ & $\begin{array}{l}\text { Guidance }{ }^{31} \text {, Other legislation: reporting of diseases, water } \\
\text { supply (water fittings), notification of cooling towers, } \\
\text { TM13 }{ }^{32}, \text { HPA }^{33}, \text { HPSC }^{34}, \text { BS }^{35} \\
\end{array}$ \\
\hline \multirow[t]{2}{*}{ Finland } & & & & & & & & - Health protection & \\
\hline & & & & & & & & $\begin{array}{l}\text { - Building code } \\
\text { - Communicable } \\
\text { diseases }\end{array}$ & \\
\hline \multirow[t]{2}{*}{ France } & partially & & & & & & $\begin{array}{l}250- \\
10000\end{array}$ & $\begin{array}{l}\text { - Public health } \\
\text { - Drinking water }\end{array}$ & \\
\hline & & & & & & & $\mathrm{cfu} / \mathrm{l}$ & - Environment & \\
\hline \multirow[t]{2}{*}{ Germany } & & & & & & & $\begin{array}{l}10000 \\
\mathrm{cfu} /\end{array}$ & $\begin{array}{l}\text { - Public health } \\
\text { - Drinking water }\end{array}$ & $\begin{array}{l}\text { - Code of practice W551 (April 2004), W556 (2015), } \\
\text { VDI/DVGW Guideline } 6023 \text { (2012), IPA }\end{array}$ \\
\hline & & & & & & & $100 \mathrm{ml}$ & & \\
\hline Hungary & & & & & & & & & - There are plans to develop regulations on general \\
\hline \multirow[t]{2}{*}{ Ireland } & & & & & & & & - Labor safety & - Guidelines \\
\hline & & & & & & & & & $\begin{array}{l}\text { - Special attention is given to potential risks of dentist } \\
\text { systems and high risk in hospitals }\end{array}$ \\
\hline Italy & & & & & & & & - Public health & - Guidelines for the prevention and control of legionellosis \\
\hline \multirow[t]{2}{*}{ Latvia } & & & & & & & & - Labor safety & \\
\hline & & & & & & & & - Public health & \\
\hline \multirow[t]{2}{*}{ Lithuania } & \begin{tabular}{|l|}
$\begin{array}{l}\text { hot water } \\
\text { only }\end{array}$ \\
\end{tabular} & & & & & & & $\begin{array}{l}\text { - Public health } \\
\text { - Drinking water }\end{array}$ & $\begin{array}{l}\text { Recommendations mainly aimed at clinical manifestation, } \\
\text { diagnostics and treatment of legionellosis }\end{array}$ \\
\hline & & & & & & & & & $\begin{array}{l}\text { - Lithuanian hygiene standard } \\
\text { - Draft of regulations for legionellosis aimed at prevention } \\
\text { in institutions and accommodation where water is stored or } \\
\text { used for work }\end{array}$ \\
\hline \multirow[t]{2}{*}{ Malta } & & & & & & & & - Public health & - Code of practice for prevention of Legionnaires' Disease \\
\hline & & & & & & & & & in hotels and other establishments \\
\hline \multirow{2}{*}{$\begin{array}{l}\text { The } \\
\text { Netherlands }\end{array}$} & & & & & & & \multirow{2}{*}{$\begin{array}{l}100 \\
\mathrm{cfu} / \mathrm{l}\end{array}$} & \multirow{2}{*}{$\begin{array}{l}\text { - Drinking water } \\
\text { - Bathing hygiene } \\
\text { - Safe labor } \\
\text { - Infectious diseases } \\
\text { - Public health }\end{array}$} & \multirow{4}{*}{$\begin{array}{l}\text { - Drinking water decree and guidance document (ISSO- } \\
\text { - publication 55) } \\
\text { - Decree on bathing locations and guidance document } \\
\text { - Policy rule on working conditions } \\
\text { - Public Health Act } \\
\text { - Act on infectious diseases } \\
\text { - Regulations on Legionella prevention in drinking water } \\
\text { under discussion } \\
\text { - Regulation of new buildings construction under discussion } \\
\text { - Act on infectious diseases and infections }\end{array}$} \\
\hline & & & & & & & & & \\
\hline \multirow[t]{2}{*}{ Poland } & & & & & & & & & \\
\hline & & & & & & & & & \\
\hline \multirow[t]{2}{*}{ Portugal } & & & & & & & & & - Elaboration of legislation concerning installation and use \\
\hline & & & & & & & & & - Prevention guidelines \\
\hline \multirow[t]{2}{*}{ Slovenia } & & & & & & & & - Environment & \\
\hline & & & & & & & & - Building & \\
\hline Sweden & & & & & & & & - Public health & - Mandatory regulations and general recommendations \\
\hline & & & & & & & & construction & \\
\hline Turkey & & & & & & & & & \\
\hline
\end{tabular}

Table 2. Summary of regulations and guidelines in European countries (adapted from ${ }^{23}$ ). 


\section{United States of America}

In the USA, there were only guidelines but no regulations until 2015. In 2015 the first official requirement was released to test for Legionella in cooling towers, this was followed in 2016 by the requirement to test for Legionella in health care facilities. ${ }^{37}$

\section{ASTM and CDC (government)}

Centers for Disease Control and Prevention Guidelines (CDC) exist for prevention of and reaction to outbreaks. 38,39,40,41,42 There is a toolkit available on their website which is very useful for developing a Legionella water management program. ${ }^{43,44}$ There is also the Industrial Hygiene Association Guideline (IHA) with recommendations for Legionella testing.

ASTM D5952-08 is the Standard Guide for the Inspection of Water Systems for Legionella and the Investigation of Possible Outbreaks of Legionellosis (Legionnaires' Disease or Pontiac Fever) dating from $2015 .^{45}$ The guide explains appropriate responses for employers, building owners and operators, facility managers, health and safety professionals, public health authorities, and others to a concern that a water system may be infected with Legionella and to the identification of one or more cases of Legionnaires' Disease or Pontiac Fever. ${ }^{46}$

In 2016, Legionella made the drinking water contaminants list of the United States Environmental Protection Agency (EPA). In 2017, the Centers for Medicare and Medicaid Services (CMS) released a mandate requiring all certified hospitals to have potable water testing and water management plans that meet ASHRAE industry standards in order to reduce the Legionella risk.

\section{ASHRAE Standard and Guideline (industry)}

ASHRAE Guideline 12-2000 Minimizing the Risk of Legionellosis Associated with Building Water Systems provides specific environmental and operational guidelines in order to minimize the risk of Legionella infection in building water systems. ${ }^{47}$ ASHRAE is currently working on a revision of these guidelines (2017).

In 2015, ASHRAE released a standard for Legionella risk management. This was the first Legionella standard in the USA. ANSI/ASHRAE Standard 188-2015 Legionellosis: Risk Management for Building Water Systems provides minimum Legionellosis risk management requirements for the design, construction, commissioning, operation, maintenance, repair, replacement, and expansion of new and existing buildings and their water systems 
and components. ${ }^{48}$ The publication includes a description of environmental conditions that promote Legionella growth and the creation a risk management process to be implemented by building owners or managers.

The applicability of the standard depends on a survey of the building's risk factors based on listed criteria. ${ }^{49}$ The standard provides a basis for identifying systems that pose a risk for Legionellosis. If the building has one or more risk factors, then ASHRAE Standard 188 applies dependent on the nature and number of risk factors being identified. In some cases Standard 188 also requires the site manager to develop a water management program. There is also a specific section of Standard 188 that provides specific guidance for health care facilities. The ASHRAE Standard does not provide a large amount of guidance on temperatures, water treatment strategies or testing limits. ${ }^{41}$ No critical levels of concentration are mentioned.

However in the public review draft BSR/ASHRAE Standard 188P: Prevention of Legionellosis Associated With Building Water Systems water temperature recommendations for Legionella control are as follows: the hot water heater outlet temperature should be at or above $60^{\circ} \mathrm{C}$, the hot water temperature at the coldest point in the hot water heater, storage tank or distribution system at or above $51{ }^{\circ} \mathrm{C}$ and the cold water temperature in any part of the system at or below $25^{\circ} \mathrm{C}$. If the HACCP (Hazard Analysis and Critical Control Points) team determines that these temperatures cannot be achieved, then it may conclude that additional hazard control measures are required. ${ }^{50}$

\section{Asia}

\section{China}

In China, there is only a code of practice for water-cooled air conditioning systems (2006). ${ }^{51}$ Additionally there is a code of practice in Hong Kong. The Code of Practice for Prevention of Legionnaires' Disease was first published by the Prevention of Legionnaires’ Disease Committee (PLDC) in 1994 and subsequently revised in 2000, 2007 and 2012. ${ }^{52}$ Taking into account the experience and the evolving knowledge of other countries and lessons from major cases in the past, this revised edition formulates strategies on Legionnaires' Disease prevention. It is featured with enhanced precautions in association with hot and cold water supply systems, from which broader practical guidelines for proper design, operation, maintenance and handling of related facilities or materials to avoid the spread of L. pneumophila bacteria can be derived. The objects of the Code are cooling towers, air-conditioning systems, hot water supply systems, cold water supply systems, architectural fountains, spa pools (whirlpools) and other water using devices. The Code contains several chapters (Appendix A). 
The Code states that the hot water storage tank of the system (directly or indirectly heated calorifier, storage vessel, ...) shall be designed to operate at $60^{\circ} \mathrm{C}$ or above to effectively kill the bacteria and that the water temperature in all the distribution pipework before reaching the thermostatic mixing valve or the tap outlet (for systems without mixing valve) shall be at least $50^{\circ} \mathrm{C}$. However, in places where people with decreased self-care ability may use hot water (pediatric, geriatric and psychiatric wards of hospitals, elderly homes, residential care homes for persons with disabilities, ...), the hot water supply temperature at outlets shall not exceed $43^{\circ} \mathrm{C}$ to prevent accidental scalding. No critical concentration levels are mentioned.

\section{Singapore}

In Singapore there is a Code of Practice for the Control of Legionella Bacteria in Cooling Towers published by the Institute of Environmental Epidemiology (IEE) ${ }^{53}$ No critical Legionella concentration levels are mentioned.

\section{Dubai}

In Dubai, there are Legionella guidelines and regulations, but the guidelines are enforced too. The difference with other countries is that there is a big focus on the use of seawater. Dental clinics have separate guidelines. ${ }^{54}$

\section{Russia}

In 1981, the first Russian Legionella guidelines appeared (update in 2017). In total there are seven national guidelines and recommendations (2007) concerning monitoring. In 2010, national rules for prevention of Legionellosis were enforced and target levels were determined. For hospitals for example, there is zero tolerance $(0 \mathrm{cfu} / \mathrm{l}){ }^{55}$

\section{Other countries}

There is a combined standards association of New Zealand and Australia about air handling and water systems of buildings-microbial control. ${ }^{56}$

\section{New Zealand}

The guideline The Prevention of Legionellosis in New Zealand: Guidelines for the Control of Legionella Bacteria aims to increase awareness about the hazards associated with Legionella, improve the management of potential sources of Legionella and improve reporting and investigation of cases of Legionellosis. ${ }^{57}$ It provides up-to-date information, advice and guidance for minimizing the risk of significant infection in water of cooling towers and cold and hot water distribution systems. It is intended to assist all those concerned with Legionella, including 
public health service providers, territorial local authorities, building owners, air conditioning engineers, employers and others dealing with building maintenance. No critical concentration levels are mentioned.

\section{Australia}

In Australia, there are over 25 guidelines, codes and regulations that do not all agree on the same things. ${ }^{58}$ There have been Guidelines for the Control of Legionnaires' Disease since 1988 (update in 1999) and a Code of Practice for the Control of Legionnaires' Disease since $2004 .^{59,60,61}$ The purpose of this code of practice is to assist and provide guidance to all those concerned with various aspects of microbial control in various specific systems which may harbor Legionella. This code emphasizes water and air systems of buildings but the content is equally applicable to equivalent industrial processes, such as power stations and process heat rejection devices that use water. No critical concentration levels are mentioned, except for $10 \mathrm{cfu} / \mathrm{ml}$ as threshold level for cooling towers. ${ }^{62}$ There is also a guide to develop risk management plans for cooling tower systems. ${ }^{63}$

\section{Africa}

South Africa has Regulations for Hazardous Biological Agents in which Legionella is identified. They demand the acceptance of responsibility for the control of exposure of individuals to Legionella and highlight the need for adequate training and information, risk assessment, monitoring and record keeping. ${ }^{64,65}$ The limitation is that the regulations are generic and applicable to all entities identified as hazardous biological agents, with no defined and legislated code of practice specific to Legionella monitoring and control. ${ }^{66}$ No guidelines are applicable for other parts of Africa.

\section{South America}

Most countries in South America are also referring to ASHRAE Standard $188 .{ }^{67}$ In Brazil Legionella is not a notifiable disease. Legionella is included in Law 6.938/81 (Environmental Act). The act mentions that harmful environmental infection by Legionella makes the responsible liable in case of human negligence by not taking reasonable measures for non-proliferation. ${ }^{68}$

\section{Key factors of regulations}

The key points of the regulations are summarized in Table 3. In the first column the authority (organization, country or continent) is mentioned, in the following columns the following questions are answered. Is Legionella 
a reportable disease? Are there any testing guidelines? Have action levels for sampling results been determined?

Are there maintenance strategies? Are there mitigation plans?

\begin{tabular}{|c|c|c|c|c|c|}
\hline & $\begin{array}{l}\text { Reportable } \\
\text { disease }\end{array}$ & $\begin{array}{l}\text { Presence of } \\
\text { testing guidelines }\end{array}$ & $\begin{array}{l}\text { Action levels for } \\
\text { sampling results }\end{array}$ & $\begin{array}{l}\text { Preventive maintenance } \\
\text { strategies }\end{array}$ & $\begin{array}{l}\text { Mitigation } \\
\text { plans }\end{array}$ \\
\hline WHO & $\begin{array}{l}\text { Reportable in } \\
\text { some } \\
\text { countries }\end{array}$ & $\begin{array}{l}\text { Testing is } \\
\text { recommended, } \\
\text { requirements and } \\
\text { frequencies are } \\
\text { included }\end{array}$ & $\begin{array}{l}\text { Only for cooling } \\
\text { water systems }\end{array}$ & $\begin{array}{l}\text { Temperature } \\
\text { (recommended temperature } \\
\text { for storage and distribution } \\
\text { of cold water is below } \\
25^{\circ} \mathrm{C} \text {, and ideally below } \\
20^{\circ} \mathrm{C} \text {. For hot water they } \\
\text { only state that the hot water } \\
\text { temperature should be } \\
\text { maintained) }\end{array}$ & $\begin{array}{l}\text { Disinfection, } \\
\text { cleaning, } \\
\text { monitoring } \\
\text { and regular } \\
\text { service and } \\
\text { maintenance }\end{array}$ \\
\hline EWGLI & $\begin{array}{l}\text { Reportable in } \\
\text { some } \\
\text { counties } \\
(\mathrm{UK}, . .), \\
\text { reporting of } \\
\text { travel } \\
\text { associated } \\
\text { cases }\end{array}$ & $\begin{array}{l}\text { Testing is } \\
\text { recommended, } \\
\text { requirements and } \\
\text { frequencies are } \\
\text { included }\end{array}$ & $\begin{array}{l}\text { Different actions } \\
\text { required between } \\
1000 \text { and } 10000 \\
\text { and above } 10 \\
000 \mathrm{cfu} / 1\end{array}$ & $\begin{array}{l}\text { Temperature (total volume } \\
\text { of the tank needs to be } \\
\text { heated up to } 60^{\circ} \mathrm{C} \text { for at } \\
\text { least an hour a day or a } \\
\text { week, depending on the } \\
\text { risk, cold water below } \\
25^{\circ} \mathrm{C} \text { ), chlorination on Italy }\end{array}$ & $\begin{array}{l}\text { Risk } \\
\text { assessment } \\
\text { and } \\
\text { management } \\
\text { plan in } \\
\text { combination } \\
\text { with regular } \\
\text { measurement } \\
\text { s }\end{array}$ \\
\hline USA & Reportable & $\begin{array}{l}\text { Recommenda- } \\
\text { tions for } \\
\text { Legionella testing }\end{array}$ & Not included & $\begin{array}{l}\text { Temperature (hot water } \\
\text { heater outlet temperature } \\
\text { should be at or above } 60^{\circ} \mathrm{C} \text {, } \\
\text { hot water temperature at } \\
\text { the coldest point in the hot } \\
\text { water heater, storage tank } \\
\text { or distribution system at or } \\
\text { above } 51^{\circ} \mathrm{C} \text { and the cold } \\
\text { water temperature in any } \\
\text { part of the system at or } \\
\text { below } 25^{\circ} \mathrm{C} \text { ), standard } \\
\text { chlorination }\end{array}$ & $\begin{array}{l}\text { Creation and } \\
\text { implementa- } \\
\text { tion of a risk } \\
\text { management } \\
\text { process and } \\
\text { Legionella } \\
\text { water } \\
\text { management } \\
\text { program }\end{array}$ \\
\hline Asia & $\begin{array}{l}\text { Only } \\
\text { reportable in } \\
\text { Hong Kong }\end{array}$ & Not included & $\begin{array}{l}\text { Not included, } \\
\text { only target levels } \\
\text { in Russia }\end{array}$ & $\begin{array}{l}\text { Temperature (hot water } \\
\text { production above } 60^{\circ} \mathrm{C} \text { ) }\end{array}$ & Not included \\
\hline \multicolumn{6}{|l|}{$\begin{array}{l}\text { Other } \\
\text { countries }\end{array}$} \\
\hline $\begin{array}{r}\text { New } \\
\text { Zealand }\end{array}$ & $\begin{array}{l}\text { Not } \\
\text { reportable }\end{array}$ & $\begin{array}{l}\text { Some } \\
\text { recommendations }\end{array}$ & Not included & Temperature & Not included \\
\hline Australia & Reportable & Not included & $\begin{array}{l}\text { Not included, } \\
\text { except for } \\
\text { 10cfu/ml for } \\
\text { cooling towers }\end{array}$ & Temperature & $\begin{array}{l}\text { Risk } \\
\text { management } \\
\text { plans for } \\
\text { cooling tower } \\
\text { systems }\end{array}$ \\
\hline Africa & $\begin{array}{l}\text { Not } \\
\text { reportable }\end{array}$ & Not included & Not included & Temperature & Not included \\
\hline $\begin{array}{r}\text { South } \\
\text { America }\end{array}$ & $\begin{array}{l}\text { Only } \\
\text { reportable in } \\
\text { Brazil }\end{array}$ & Not included & Not included & Temperature & Not included \\
\hline
\end{tabular}

Table 3. Key factors of regulations. 


\section{What about temperature levels?}

Different authorities have different temperature regulations. ${ }^{69}$ These regulations are summarized in Table 4 . In the first column the authority (organization, country or continent) is mentioned, in the second the required temperature at the water heater, in the third column the required temperature at the return loop and in the fourth column the required temperature at the points of use.

\begin{tabular}{r|l|l|l}
\hline & Water heater & Return loop & Point of use \\
\hline WHO & $>60^{\circ} \mathrm{C}$ & $>55^{\circ} \mathrm{C}$ & $\geq 50^{\circ} \mathrm{C}($ after 1 minute $)$ \\
EWGLI & $\geq 60^{\circ} \mathrm{C}(1$ hour a day/week) & $\geq 55^{\circ} \mathrm{C}$ & $\geq 55^{\circ} \mathrm{C}\left(70^{\circ} \mathrm{C}\right.$ should be possible $)$ \\
UK & $\geq 60^{\circ} \mathrm{C}$ & $\geq 50^{\circ} \mathrm{C} /$ loop & $\geq 55^{\circ} \mathrm{C}$ (health care $)$ \\
France & $>55^{\circ} \mathrm{C}\left(\right.$ recommendation $\left.\geq 60^{\circ} \mathrm{C}\right)$ & $>50^{\circ} \mathrm{C}$ & $\geq 50^{\circ} \mathrm{C}$ \\
USA & $\geq 60^{\circ} \mathrm{C}$ & $\geq 51^{\circ} \mathrm{C}$ & $\geq 43.3-49^{\circ} \mathrm{C}$ (health care $)$ \\
Asia & $\geq 60^{\circ} \mathrm{C}$ & $/$ & $\geq 50^{\circ} \mathrm{C} / \leq 43^{\circ} \mathrm{C}$ (health care $)$ \\
\hline
\end{tabular}

Table 4. Comparison of temperature regulations by different authorities. ${ }^{59}$

\section{Concerning chemical disinfection techniques}

Subsequently the use of chemical disinfection is region dependent. Free chlorine is mostly used at a low concentration $(0.2-0.5 \mathrm{mg} / \mathrm{l})$ as a secondary disinfectant for the maintenance of water quality in distribution systems or at higher concentrations as an installation disinfection treatment called hyper chlorination. ${ }^{70}$ Chlorination has many disadvantages. 4 to $6 \mathrm{mg} / \mathrm{l}$ of chlorine only provides $90 \%$ kill of L. pneumophila species.

The national/local regulations concerning the admissible quantity of free chlorine present in drinking water (at the user outlet) can vary from 0.1 to $1 \mathrm{mg} / 1 .{ }^{59,71}$ In Belgium for example, the maximum concentration of chlorine is $0.25 \mathrm{mg} / \mathrm{l} .{ }^{72}$ In Germany 0.2 to $0.4 \mathrm{ppm}$ of chlorine dioxide can be injected in water. This $0.4 \mathrm{ppm}$ limit of chlorine dioxide is the highest in Europe. In Denmark, the addition of chlorine dioxide is prohibited in cold water, it is only allowed in hot water. Overall, in countries like Germany or Belgium chemical disinfection is avoided because of its disadvantages. First it can damage plumbing components and secondly the effect on human health on the long term is unknown. German risk regulation states: "Water is free from any micro-organism which constitutes a potential danger to human health". ${ }^{73}$ In Germany, Belgium and The Netherlands disinfectants are not used as preventive measure but are solely used at outbreaks. In Italy, this is impossible because of the high cold water temperature causing Legionella growth in cold water.

In Europe, thermal treatment is recommended. Alternative treatments are only permitted in case thermal treatment is insufficient. Alternative treatments are recommended in following order: first physical disinfection 
(pasteurization, UV, micro- and ultra-filtration) followed by electrochemical disinfection (copper-silver ionization, anodic oxidation) and as a very last option chemical disinfection (free chlorine, chlorine dioxide, ...).

\section{RESULTS}

\section{Similarities in current regulations}

By reviewing existing Legionella regulations and guidelines, it can be noticed that they have multiple similarities. Despite different regulatory frameworks, there is a broad unification of three principles. First, almost all guidelines have a section about avoiding and monitoring critical spots. Critical spots are locations in a hot water installation where water stays in the L. pneumophila growth temperature range for a certain time. They need to be inspected properly in order to notice problems quickly so as to limit possible infection.

Secondly, several guidelines mention measures to avoid water stagnation in certain parts of the systems so as to avoid L. pneumophila proliferation.

Thirdly, the most commonly used measure in many countries is the requirement of a sufficiently high temperature to prevent the growth of L. pneumophila Most countries set hot water temperature requirements for the water heater, the return loop and the points of use as well as cold water temperature requirements. EWGLI recommends that the total volume of the storage tank needs to be heated up to $60^{\circ} \mathrm{C}$ for at least an hour a day or a week, depending on the risk. It should be possible to achieve a temperature of $70^{\circ} \mathrm{C}$ at every tap. Cold water temperature should be kept lower than $25^{\circ} \mathrm{C}$. The temperature at the end of the circulation system cannot be more than $5^{\circ} \mathrm{C}$ lower than the supply temperature at the storage tank. The code in China states that the hot water storage device of the system shall be designed to operate at $60^{\circ} \mathrm{C}$ and that water temperature in all distribution pipework shall be at least $50^{\circ} \mathrm{C}$. Other standards like ASHRAE do not provide a large amount of guidance on temperatures or water treatment strategies, except for the temperatures mentioned in the draft BSR/ASHRAE Standard 188P that have however not been translated into ASHRAE Standard 188.

\section{Comparison with other references}

Many of the published guidance and standards are not necessarily evidence based. That is why for each common item that has been identified, references to scientific (clinical) studies that support the importance of these items are given, if available. The precision, accuracy and effectiveness of ways to estimate the risk of higher Legionella 
numbers have only rarely been empirically assessed in practice, although there is a broad consensus about the impact of these risk factors. ${ }^{74}$

\section{Avoiding and monitoring problematic locations in the system}

The paper of Harper (1988) deals with the engineering implications of Legionnaires' Disease outbreaks. ${ }^{75}$ The aim of the paper is to set out steps that might be taken when a hospital outbreak occurs and a water system is identified as the source. Results are based on case study experience. Cabanes et al. (1995) presented preliminary data about a method of risk assessment of a water distribution system in France. ${ }^{76}$ They emphasize the lack of data, especially in France, with regard to risk evaluation related to the development of Legionella in individual hot water supply systems. Ha et al. (2006) wrote a combined biological/engineering paper dealing with an outbreak in Pas-de-Calais (France). ${ }^{77}$ Frayne discusses the need for, and use of, active monitoring, control, and management of waterside environments in cooling, heating, and potable water systems. ${ }^{78}$ Blanky et al. (2015) wrote a combined biological/engineering paper dealing with monitoring Legionella presence from potable water to treated greywater. ${ }^{79}$ Vance (2015) researched the ecological niche of Legionella, the diagnosis of human infection, and its isolation from the environment. ${ }^{80}$

\section{Avoiding water stagnation points in the system}

Stagnation within water systems has been cited by numerous authors as a condition favouring Legionella replication. ${ }^{81,82}$ However, the effect of low flow conditions on the presence of L. pneumophila in a water system has not been scientifically evaluated. ${ }^{83}$ Völker et al. found by logistic regression modelling that occurrences of $L$. pneumophila $(>100 \mathrm{cfu} / 100 \mathrm{ml})$ at single outlets were significantly correlated with three parameters, first temperature after flushing until no significant changes in temperatures can be obtained, secondly stagnation (low withdrawal, qualitatively assessed) and thirdly pipe length. ${ }^{74}$ They predicted the impact of each variable on the Legionella infection risk.

\section{Appropriate temperature management to prevent growth}

Multiplication of L. pneumophila is dependent on the water temperature. This relation has been found by studying L. pneumophila bacteria in laboratory conditions. ${ }^{84}$ At temperatures below $20^{\circ} \mathrm{C}$, the bacteria become dormant but remain viable for months. The bacteria grow best at temperatures between $20^{\circ} \mathrm{C}$ and $45^{\circ} \mathrm{C}$ with an optimum around $35^{\circ} \mathrm{C}-41^{\circ} \mathrm{C}$. Beyond $45^{\circ} \mathrm{C}$, pasteurization starts and higher temperatures will eventually kill the organism. The 
time to double the number of L. pneumophila cells in water is less than half a day at $41^{\circ} \mathrm{C}$ and at $70^{\circ} \mathrm{C} 90 \%$ of $L$. pneumophila in water gets killed in less than a minute.

Spinks et al. investigated the health risks of the use of harvested rainwater in DHW systems. ${ }^{85}$ The results of this study were that the temperature range from $55^{\circ} \mathrm{C}$ to $65^{\circ} \mathrm{C}$ was critical for effective elimination of enteric/pathogenic bacterial components and supported the thesis that hot water systems should operate at a minimum of $60^{\circ} \mathrm{C}$.

\section{Differences in current regulations}

Notwithstanding the multiple similarities, it can also be noticed that current Legionella regulations and guidelines have some differences. First, the target group is often very specific. A large proportion of the documents is applicable on a limited group of buildings, namely health care or cooling towers. In health care facilities the risk of infection is higher due to the user's age and/or health status. Furthermore, the typical type of system present in hospitals is circulation systems which are more vulnerable to Legionella infection. Other services like collective DHW systems in sport centers or apartment buildings are often not part of the guidelines or regulations, only sufficiently high temperature should be kept in their storage tanks. This is at least remarkable because the European Union (EWGLI) sets no restriction to public establishments and their measures are valid for both cold and hot water installations.

Secondly, the definition of dangerous Legionella concentration levels varies between countries. EWGLI demands different measures for concentrations between 1000 and $10000 \mathrm{cfu} / 1$ and more than $10000 \mathrm{cfu} / 1$. European countries are not obliged to follow the critical concentrations set by EWGLI causing differences between countries. The defined critical concentration limit is lowest in The Netherlands with 100cfu/l for priority institutions. In neighboring Belgium, a similar device (for example of a hospital) should be closed for usage after repeated occurrence of $10000 \mathrm{cfu} / \mathrm{l}$ in the installation. A factor 100 difference is at least remarkable in a period of everincreasing integration of European legislations. Most non-European documents (like ASHRAE) do not include critical levels, nor do they provide a large amount of guidance on testing limits.

Finally, most guidelines and regulations are talking about Legionella in general, but L. pneumophila is actually meant, this could be specified in future updates and unification of the guidelines. 


\section{Comparison with other references}

Although there is no information available on the infective dose for humans, it can be assumed to be low for susceptible people, as illnesses have occurred after short exposures and at three or more $\mathrm{km}$ from the source of outbreaks. The likelihood of illness depends on the concentrations of Legionella in the water source, the production and dissemination of aerosols, host factors such as age and pre-existing health conditions and the virulence of the particular strain of Legionella. At the same time it has to be recognized that most infections do not cause illness. ${ }^{3}$

\section{DISCUSSION AND PERSPECTIVES ON LEGIONELLA REGULATIONS}

Comparing frameworks can be a start to reach future unification of Legionella regulations. Current regulations enclose a wide range of climatologic circumstances. Still no different measures are recommended regarding different environmental circumstances worldwide, because it are the DHW system characteristics that are dominant over different climate conditions. Clearer, more uniform and unambiguous regulations will facilitate their implementation. To conclude we can ask the question: "Do we have clear, uniform and unambiguous Legionella guidelines and regulations?". The answer is obviously: "No, we have not". BUT, despite different regulatory frameworks, there is a broad unification of principles.

\section{FUTURE RESEARCH}

This paper is the documentation of a broad summary of different standards, guidelines and recommendations of how various authorities worldwide deal with Legionella prevention and infection. The comparative analysis is a good starting point to reach future unification of the different regulatory frameworks. The current guidelines and standards are not the most clear, uniform and unambiguous, but the underlying principles are already broadly unified. In a global market, it should thus be possible to reduce the number of guidelines, standards and regulations to reach more unified documents without losing important country specific nuances.

In future, with the aim of more energy-efficient building in mind, the question will be raised whether we can reduce temperature for hot water production during certain periods of time. Simulating L. pneumophila growth can ultimately result in a more accurate prediction of the bacteria concentration and based on that gained knowledge energy saving alternatives can be researched. As such, L. pneumophila simulation can be a firm and scientific base for updating existing standards and guidelines. 


\section{ACKNOWLEDGEMENTS}

Funding details:

This research is funded by the Agency for Innovation by Science and TechnologyBelgium (IWT/VLAIO), Project 141608.

Competing interests: The authors declare that they have no conflict of interest.

Ethical approval: $\quad$ No ethical approval is required for this paper because it is a review paper and no ethical matters are presented. 


\section{APPENDIX}

\section{Appendix A Supplemental material}

\section{World Health Organisation}

WHO currently provides information and guidance on Legionella risk assessment and management in seven principal documents:

- Epidemiology, prevention and control of legionellosis ${ }^{86}$

- Recommended surveillance standards ${ }^{87}$

- Guidelines for drinking-water quality ${ }^{88}$

- Revision of the international health regulations ${ }^{89}$

- Guidelines for safe recreational water environments ${ }^{90}$

- Guide to ship sanitation ${ }^{91}$

- Legionella and the prevention of legionellosis ${ }^{92}$

\section{European Working Group for Legionella Infections (government)}

Limiting possible infection can be done with the following principles:

- Preparation of a risk assessment and management plan in combination with regular measurements.

- Presence of temperature sensors at the start and return of the circuit.

- Presence and use of valves in circuits to isolate parts that will not be used during a longer period of time.

- Presence of inspection covers at the level of the non-return valves.

- The possibility to empty the storage vessels so that they can be cleaned on a regular basis.

An overview of measures affecting the temperature in the installation is given below:

- When a storage tank is present, the total volume of the tank needs to be heated up to $60^{\circ} \mathrm{C}$ for at least an hour a day or a week, depending on the risk.

The authors of this review paper state that there is some evidence that this may not be sufficient and that this temperature is often kept continuously for simplicity of safety reasons.

- It should be possible to achieve a temperature of $70^{\circ} \mathrm{C}$ at every tap.

- When a circulation distribution system is present, the temperature at the end of the circulation system cannot be more than $5^{\circ} \mathrm{C}$ lower than the temperature of the supply at the storage tank. An exception to this rule are the end-use pipes to the different outlets that are no longer than 5 meters and contain less than 3 liters.

- Insulated pipes cause less heat losses, meaning supply and return temperatures vary less and adaptation of the allowed flow rate is not necessary.

The authors of this review paper state that insulating all pipes is not always the best solution, end-use pipes should cool down as soon as possible to limit the time in the critical temperature range for Legionella growth, so insulating them should be avoided.

- Cold water temperature should be kept lower than $25^{\circ} \mathrm{C}$ to prevent growth in the cold water circuit.

- Cold and hot water pipes cannot be located too close to each other in order to avoid cold water heating up and hot water cooling down.

The following measures avoid stagnation of water in certain parts of the systems to prevent proliferation of $L$. pneumophila:

- A simple system with few turns reduces the pressure loss and the risk of water stagnation.

- Regular use of hot water avoids dead pipe ends (tap that is no longer used). 
- Not often used outlets need to be installed upstream to limit the length of pipes with stagnant water.

- The pipes need to be flushed after a period without water use.

- Buffer reservoirs should be limited in size and number.

- Not insulating distribution pipes ensures stagnant water to cool rapidly to room temperature (shorter stay in critical temperature range).

The authors of this review paper indicate that this contradicts earlier sayings.

\section{Germany}

In Germany, there is Code of practice W551 (2004) for drinking-water installations which recommends some best plumbing practices like $\mathrm{g}^{3,94}$ :

- Keeping the stored water volume small.

- Keeping hot water temperature above $60^{\circ} \mathrm{C}$ when leaving the hot water tank and $55^{\circ} \mathrm{C}$ in circulation distribution pipes. This is in accordance with DIN1988-200, section 10.2.3.

- Keeping non-circulating (like end-use) pipes short.

- Avoiding stagnation.

- Regular maintenance and inspection of the system.

- Rehabilitation like the use of insulation and the use of electronic self-flushing taps.

- Performing of hygienic-microbiological examinations.

\section{China}

The Code of Practice for Prevention of Legionnaires' Disease contains several chapters:

- Guidelines on design, operation and maintenance of water using apparatus.

- Collection of water samples from water using apparatus for testing Legionella, Heterotrophic Colony Count (HCC) and other water quality parameters.

- Control measures during outbreak of Legionnaires' Disease.

- Design, operation and maintenance records.

- Handling garden soils, composts and potting mixes. 


\section{REFERENCES}

1. Katz SM, Hammel JM. The effect of drying, heat, and PH on the survival of Legionella pneumophila. Annals of clinical and laboratory science 1987;17(3):150-156.

2. Centers for Disease Control and Prevention. Surveillance and reporting. https://www.cdc.gov/legionella/survreporting.html; 2017 [accessed 29 January 2018].

3. World Health Organization. Legionellosis fact sheet. http://www.who.int/mediacentre/factsheets/fs285/en/; 2016 [accessed 16 May 2017].

4. TETRA. TETRA SWW project and Instal2020 project, presentations; 2015.

5. Campo AM, Apraiz D. Epidemiological study of the Legionella pneumophila presence in potable water in Alicante municipal waters of Alicante, Spain. Aqua (The Journal of the International Water Supply Association) 1988;3:116-119.

6. Colbourne JS, Dennis PJ. The ecology and survival of Legionella Pneumophila. Thames Water Authority Journal of the Institution of Water and Environmental Management 1989;3(4):345-350.

7. Colbourne JS, Dennis PJ, Trew RM, Berry C, Vesey G. Legionella and Public Water Supplies. Water Science and Technology 1988;20(11-12):5-10.

8. Voss L, Button KS, Lorenz RC, Tuovinen OH. Legionella Contamination of a Preoperational Treatment Plant. Journal of the American Water Works Assoc 1986;78(1):70-75.

9. EPA. Legionella Criteria Document. United States Environmental Protection Agency, Office of Water. Washington DC [USA]; 1985.

10. Herrera-Lara S, Fernandez-Fabrellas E, Cervera-Juan A, Blanquer-Olivas R. Do Seasonal Changes and Climate Influence the Etiology of Community Acquired Pneumonia? Archivos de Bronconeumologia 2013;49(4):140-145.

11. World Health Organization. Legionella and the prevention of legionellosis; 2007.

12. American Society of Heating, Refrigerating and Air-Conditioning Engineers. Guideline 12-2000 Minimizing the risk of legionellosis associated with building water systems. Atlanta, Georgia [USA]; 2000.

13. Health and Safety Commission, United Kingdom. Legionnaires' disease. The control of legionella bacteria in water systems. Approved code of practice and guidance. Norwich; 2000.

14. Allegheny County Health Department. Approaches to prevention and control of Legionella infection in Allegheny County health care facilities. Pittsburgh, Philadelphia [USA]; 1997.

15. Ehrlich RL, Steele MS, Sabatini NJ. Report of the Maryland Scientific Working Group to study Legionella in water systems in healthcare institutions. State of Maryland Department of Health and Mental Hygiene, http://www.dhmh.state.md.us/html/legionella.htm; 2000 [accessed 24 March 2017].

16. Centers for Disease Control and Prevention. Guidelines for environmental infection control in health-care facilities. Atlanta, Georgia [USA]; 2003.

17. Centers for Disease Control and Prevention. Comprehensive plan for epidemiologic surveillance. Atlanta, Georgia [USA]; 1996.

18. Centers for Disease Control and Prevention. Guidelines for prevention and control of nosocomial pneumonia. Morbidity and Mortality Weekly Report 1997;46:31-34.

19. Centers for Disease Control and Prevention. Final recommendations to minimize transmission of Legionnaires' disease from whirlpool spas on cruise ships. United States Department of Health and Human Services, Public 
Health Service, National Center for Environmental Health/National Center for Infectious Diseases. Atlanta, Georgia [USA]; 1997.

20. Centers for Disease Control and Prevention. Guidelines for environmental infection control in health-care facilities. Atlanta, Georgia [USA]; 2003.

21. EWGLINET. European guidelines for control and prevention of travel associated Legionnaires' disease. EWGLI, http://www.ewgli.org/public_info/publicinfo_touroperators.asp; 2013 [accessed 24 March 2017].

22. World Health Organization. Guide to Ship Sanitation, 2nd ed, Geneva [Switzerland]; 2007.

23. EWGLI. The European Working Group for Legionella Infections, http://www.ewgli.org; 2010 [accessed 16 October 2017].

24. Jozeph C, Lee J et al. Technical Guidelines for the Investigation, Control and Prevention of Travel Associated Legionnaires’ Disease. European Working Group for Legionella Infections. London [UK]; p. 41.

25. La Mura S, Joppolo CM, Piterà LA, Angermann JP, Izard M. REHVA Guidebook: Legionellosis Prevention in Building Water and HVAC Systems. 18; 2013.

26. Suchenwirth R. Compliance with Drinking Water System Regulations: The German Approach. Lower Saxony Health Authorities, Hannover, Germany. Presentation at $9^{\text {th }}$ International Conference on Legionella, September $26^{\text {th }}-30^{\text {th }} 2017$. Rome [Italy]; 2017.

27. Pleischl S. Technical prerequisites for a safe Drinking Water System for Legionella. University of Bonn, Bonn, Germany. Presentation at $9^{\text {th }}$ International Conference on Legionella, September $26^{\text {th }}-30^{\text {th }} 2017$. Rome [Italy]; 2017.

28. Exner M, Pleischl S. The German Experiences with Legionella Risk Regulation. Institute for Hygiene and Public Health, University of Bonn, WHO Collaborating Centre for Health Promoting Water Management, Germany. Presentation at $9^{\text {th }}$ International Conference on Legionella, September $26^{\text {th }}-30^{\text {th }} 2017$. Rome [Italy]; 2017.

29. Kreps S, De Cuyper K, Vanassche S, Vrancken K. Beste Beschikbare Technieken (BBT) voor Legionellabeheersing in Nieuwe Sanitaire Systemen. Belgium; 2007.

30. World Health Organization. Legionella and the prevention of legionellosis; 2007.

31. Approved Code of Practice and Guidance. The Control of Legionella Bacteria in Water Systems, Health and Safety Executive. UK; 2004.

32. TM13:2002. Minimising the Risk of Legionnaires’ Disease. CIBSE, UK; 2002.

33. Health Prevention Agency. Management of SPA Pools: Controlling the Risk of Infection. UK; 2006.

34. Health Protection Surveillance Centre. National Guidelines for the Control of Legionellosis in Ireland. Ireland; 2009.

35. The British Standards Institution. BS 6700:2006+A1:2009: Design, installation, testing and maintenance of services supplying water for domestic use within buildings and their curtilages. UK; 2009.

36. ISSO-publicatie 55. Leidingwaterinstallaties. Voor woon- en utiliteitsgebouwen. The Netherlands; 2013.

37. Stout J. U.S. Guidance and Standards. Special Pathogens Laboratory, Pittsburgh, United States of America. Presentation at $9^{\text {th }}$ International Conference on Legionella, September $26^{\text {th }}-30^{\text {th }} 2017$. Rome [Italy]; 2017.

38. Centres for Disease Control and Prevention. Comprehensive plan for epidemiologic surveillance. Atlanta, Georgia [USA]; 1996.

39. Centers for Disease Control and Prevention. Guidelines for prevention and control of nosocomial pneumonia. Morbidity and Mortality Weekly Report 1997;46:31-34. 
40. Centers for Disease Control and Prevention. Final recommendations to minimize transmission of Legionnaires' disease from whirlpool spas on cruise ships. United States Department of Health and Human Services, Atlanta, Georgia, Public Health Service, National Center for Environmental Health/National Center for Infectious Diseases; 1997.

41. Centers for Disease Control and Prevention. Guidelines for environmental infection control in health-care facilities. Atlanta, Georgia [USA]; 2003.

42. Centers for Disease Control and Prevention. Fact sheet for pool staff/owners: operating public spas. Atlanta, Georgia [USA]; 2005.

43. Cooley L. A Watershed Moment: The Increasing Challenge of Legionnaires' Disease in the United States. Presentation at $9^{\text {th }}$ International Conference on Legionella, September $26^{\text {th }}-30^{\text {th }} 2017$. Rome [Italy]; 2017.

44. Centers for Disease Control and Prevention. Developing a Water Management Program to Reduce Legionella Growth \& Spread in Buildings (toolkit); 2017.

45. ASTM D5952-08. Standard Guide for the Inspection of Water Systems for Legionella and the Investigation of Possible Outbreaks of Legionellosis (Legionnaires' Disease or Pontiac Fever), ASTM International, West Conshohocken, PA, https://www.astm.org/Standards/D5952.htm, 2015 [accessed 24 March 2017].

46. Russotti R. Legionellosis: Risk Management for Building Water Systems, https://ansidotorg.blogspot.be/2015/09/legionellosis-risk-management-for.html\#gref; 2015 [accessed 24 March 2017].

47. American Society of Heating, Refrigerating and Air-Conditioning Engineers. Guideline 12-2000 Minimizing the risk of legionellosis associated with building water systems. Atlanta, Georgia [USA]; 2000.

48. American Society of Heating, Refrigerating and Air-Conditioning Engineers. Standard 188-2015 Legionellosis: Risk Management for Building Water Systems; 2015.

49. Chemtreat. ASHRAE 188 Summary. http://www.chemtreat.com/static/media/prgLegionella.pdf; 2015 [accessed 15 May 2017].

50. BSR/ASHRAE Standard 188P. Proposed New Standard 188: Prevention of Legionellosis Associated With Building Water $\quad$ Systems. Second Public https://osr.ashrae.org/Public\%20Review\%20Draft\%20Standards\%20Lib/Std-188P-

PPR2\%20Final\%206\%2010\%202011.pdf; 2011 [accessed 18 October 2017].

51. Code of Practice for Water-cooled Air Conditioning Systems - Part 1 to Part 3. Electrical and Mechanical Services Department, Hong Kong Special Administrative Region, China; 2006.

52. PLDC. http://www.emsd.gov.hk/filemanager/en/content_296/COP-PLD_2012.pdf; 2012 [accessed 24 March 2017], p. 16.

53. Institute of Environmental Epidemiology. Code of Practice for the Control of Legionella Bacteria in Cooling Towers, Ministry of Environment, Singapore; 2001.

54. Salman R. Technology Advancement Supporting Legionella Control in Dubai. Health and Safety DepartmentDubai Municipality, Dubai UAE. Presentation at $9^{\text {th }}$ International Conference on Legionella, September $26^{\text {th }}-30^{\text {th }}$ 2017. Rome [Italy]; 2017.

55. Tartakovskiy I. Legionella Guidelines in the Russian Federation: Harmonization in Accordance to International Standards, Gamaleya Research Center of Epidemiology and Microbiology, Moscow, Russia. Presentation at $9^{\text {th }}$ International Conference on Legionella, September $26^{\text {th }}-30^{\text {th }} 2017$. Rome [Italy]; 2017.

56. Standards Association of Australia/Standards Association of New Zealand. AS/NZS 3666.1-3. Air handling and water systems of buildings-microbial control; 2002.

57. Ministry of Health. The Prevention of Legionellosis in New Zealand: Guidelines for the control of legionella bacteria, New Zealand. http://www.health.govt.nz/publication/prevention-legionellosis-new-zealand-guidelinescontrol-legionella-bacteria; 2011 [accessed 24 March 2017]. 
58. Bentham R. Legionella Regulation in Australia, Flinders University, Adelaide, Australia. Presentation at 9th International Conference on Legionella, September 26th-30th 2017. Rome [Italy]; 2017.

59. National Health and Medical Research Council. Australian guideline for the control of Legionella and Legionnaires’ disease. Australian Government Publishing Service, Canberra [Australia]; 1988.

60. Guidelines for the Control of Legionnaires' Disease. Department of Human Services, Victoria [Australia]; 1999.

61. Code of Practice for the Control of Legionnaires' Disease. New South Wales Department of Health, Australia; 2004

62. Bentham R. Legionella Regulation in Australia, Flinders University, Adelaide, Australia. Presentation at 9th International Conference on Legionella, September 26th-30th 2017. Rome [Italy]; 2017.

63. Victorian Government Department of Human Services. A guide to developing risk management plans for cooling tower systems. Melbourne, Victoria, Australia; 2001.

64. Department of Labour. Hazardous Biological Agents Regulations (GN 1390, 27 December 2001). http://www.labour.gov.za/downloads/legislation/acts/occupational-health-and-safety/; 2001 [accessed 18 October 2017], South Africa.

65. Department of Labour. Occupational Health and Safety Act, No. 85 of 1993, as amended by the Occupational Health and Safety Amendment Act, No. 181 of 1993. http://www.labour.gov.za; 1993 [accessed 18 October 2017], South Africa.

66. Sanderson A, Weehuizen A. Legionella an increased risk within South Africa; 2009.

67. BSR/ASHRAE Standard 188P. Proposed New Standard 188: Prevention of Legionellosis Associated With Building Water Systems. Second Public https://osr.ashrae.org/Public\%20Review\%20Draft\%20Standards\%20Lib/Std-188P-

PPR2\%20Final\%206\%2010\%202011.pdf; 2011 [accessed 18 October 2017].

68. Bensoussan M. Regulatory Environment/Brazil IAQ/LEGIONELLA/WSP, 1st Annual Smart Water Leadership Summit: Healthcare; s.d.

69. Bédard E, Fey S, Charron D, Lalancette C, Cartin P, Dolce P et al. Temperature diagnostic to identify high risk areas and optimize Legionella pneumophila surveillance in hot water distribution systems. Water Res. 2015. http://dx.doi.org/10.1016/j.watres.2015.01.006.

70. Cervero-Aragó S, Rodríguez-Martínez S, Puertas-Bennasar A, Araujo RM. Effect of common drinking water disinfectants, chlorine and heat, on free Legionella and amoebae-associated Legionella. PLoS ONE 2015;10(8).

71. REHVA. Guidebook: Legionellosis Prevention in Building Water and HVAC Systems. 18; 2013.

72. De Watergroep. Drinkwaterkwaliteit. http://www.dewatergroep.be/drinkwaterkwaliteit; 2017 [accessed 15 May 2017].

73. Exner M, Pleischl S. The German Experiences with Legionella Risk Regulation. Institute for Hygiene and Public Health, University of Bonn, WHO Collaborating Centre for Health Promoting Water Management, Germany. Presentation at $9^{\text {th }}$ International Conference on Legionella, September $26^{\text {th }}-30^{\text {th }} 2017$. Rome [Italy]; 2017.

74. Völker S, Schreiber C, Kistemann T. Modelling characteristics to predict Legionella contamination riskSurveillance of drinking water plumbing systems and identification of risk areas. International Journal of Hygiene and Environmental Health 2015;219:101-109.

75. Harper D. Legionnaires' disease outbreaks - the engineering implications. 1st International Conference of the Hospital Infection Society. Journal of Hospital Infection 1988;11:201-208.

76. Cabanes PA, Dubrou S, Larguier M, Saude I, Festy B. Les Legionella dans l'environnement hydrique sanitaire: Données préliminaires pour une évaluation du risque en France, Médecine et Maladies Infectieuses 1995;25(67):850-857. 
77. Ha TL. La légionellose: un risque environnemental. Archives des Maladies Professionnelles et de l'Environnement 2006;67(4):669-678.

78. Frayne C. 4.27 - Environmental Modification for Cooling, Heating and Potable Water Systems. Reference Module in Materials Science and Materials Engineering, Shreir's Corrosion 2010;4:2930-2970.

79. Blanky M, Rodríguez-Martínez S, Halpern M, Friedler E. Legionella pneumophila: From potable water to treated greywater; quantification and removal during treatment. Science of The Total Environment 2015;533:557565.

80. Vance PH, Schaeffer F, Trevino E, Weissfeld AS. Legionella: a Fascinating Bacterium Uncovered in the Twentieth Century. Clinical Microbiology Newsletter 2015;37(15):119-123.

81. Ciesielski CA, Blaser MJ, Wang WL. Role of stagnation and obstruction of water flow in isolation of Legionella pneumophila from hospital plumbing. Appl Environ Microbiol 1984;48:984-987.

82. Anon. Control of Legionellosis. II:7-1-II:7-41. Washington DC: Occupational Safety and Health Administration; 1996.

83. Liu Z, Lin YE, Stout JE, Hwang CC, Vidic RD, Yu VL. Effect of flow regimes on the presence of Legionella within the biofilm of a model plumbing system. J Appl Microbiol 2006;101:437-442.

84. Brundrett GW. Legionella and Building Services. Oxford [UK]; 1992.

85. Spinks AT, Dunstan RH, Harrison T, Coombes P, Kuczera G. Thermal inactivation of water-borne pathogenic and indicator bacteria at sub-boiling temperatures. Water Research 2006;40(6):1326-1332.

86. World Health Organization. Epidemiology, prevention and control of legionellosis. Memorandum from a WHO meeting. Bulletin of the World Health Organization 1990; 68(2):155-164.

87. World Health Organization. WHO Recommended Surveillance Standards, 2nd ed. (WHO/CDS/ CSR/ISR/99.2); 1999.

88. World Health Organization. Guidelines for Drinking Water Quality, 3rd ed. Vol. 1. Recommendations, Geneva; 2004.

89. World Health Organization. Revision of the International Health Regulations. Geneva [Switzerland]; 2005.

90. World Health Organization. Guidelines for Safe Recreational Water Environments. Volume 2. Swimming Pools, Spas and Similar Recreational Water Environments. Geneva [Switzerland]; 2006.

91. World Health Organization. Guide to Ship Sanitation, 2nd ed, Geneva [Switzerland]; 2007.

92. World Health Organization. Legionella and the prevention of legionellosis; 2007.

93. Suchenwirth R. Compliance with Drinking Water System Regulations: The German Approach. Lower Saxony Health Authorities, Hannover, Germany. Presentation at $9^{\text {th }}$ International Conference on Legionella, September $26^{\text {th }}-30^{\text {th }} 2017$. Rome [Italy]; 2017.

94. Pleischl S. Technical prerequisites for a safe Drinking Water System for Legionella. University of Bonn, Bonn, Germany. Presentation at $9^{\text {th }}$ International Conference on Legionella, September $26^{\text {th }}-30^{\text {th }} 2017$. Rome [Italy]; 2017. 